Review

\title{
The Energy of the Sea Must Begin to be Massively Extracted
}

\author{
${ }^{1}$ Nicolae Petrescu and ${ }^{2}$ Florian Ion Tiberiu Petrescu \\ ${ }^{1}$ Bucharest University, Bucharest, (CE), Romania \\ ${ }^{2}$ ARoTMM-IFToMM, Bucharest Polytechnic University, Bucharest, (CE), Romania
}

\section{Article history}

Received: $13-10-2019$

Revised: 18-10-2019

Accepted: 19-10-2019

Corresponding Author: Florian Ion Tiberiu Petrescu ARoTMM-IFToMM, Bucharest Polytechnic University, Bucharest, (CE), Romania Email: tiberiuflorianion@gmail.com

\begin{abstract}
The present paper is intended to be a plea for the extraction of energy from the seas and oceans because this energy is very large quantity from an objective point of view and in addition it is clean, renewable and sustainable, friendly and totally non-dangerous, being a very high energy which it is permanently lost, energy from which if we extract only a small amount we get enough energy for the entire planet's needs in very good and convenient conditions, without risking having nuclear residues or losses, emanations or even uncontrolled explosions that can occur at existing nuclear power plants. The seas and oceans of the planet cover about three-quarters of the total surface of our planet so that the extraction of the energy of the seas and oceans is really a permanent urge and necessity that we should see it and take it into account. The immense advantage of the energy extracted from the waters of the seas and the oceans is the constant of its production, that is to say, the extraction of a constant amount of energy, a fact that no longer meets with other energy sources, than perhaps with nuclear energy.
\end{abstract}

\section{Keywords: Energy, Water, Wave Energy, Tidal Energy}

\section{Introduction}

On our planet still blue although its colors have faded over time, water is a basic matter. Humans and animals are made up of about $70 \%$ of the water. So do the plants. So everything that is alive is full of water. The air and the entire terrestrial atmosphere also contains water. The permanent movement of water in the nature of our planet is the one that achieves the permanent cleaning of our planet. The water changes and regenerates permanently so that it allows a total or partial cleaning of the planet we live on. So we can say that on our planet water is a basic matter, that is, essential, without which the life and health of the planet would no longer be possible. The air is also cleaned largely due to the water it contains. The terrestrial atmosphere is not only composed of oxygen and nitrogen, to which various residues (such as burnt hydrocarbons, fluorine...) are added, but also contain water especially in the form of water vapor. Cloud formation when the amount of water is high so that the water will flow and then flow to the ground to cool it and refresh it is an essential phenomenon that will not be able to repeat infinitely at the normal rate if we continue to cut massively. the forests of the planet, to set them on fire and not to forestall them again quickly (Aversa et al., 2017).

Ozone is permanently restored due to the water in the atmosphere because the flashes of lightning generated by the water clouds have the role of producing massive ozone, with the obvious purpose of permanently restoring the ozone protective layer.

Without forests there would be no new water vapor in the atmosphere and the clouds would not recover, so there would be no rain and no lightning so no ozone and no protective layer on the planet. There are so-called gimmicks that cut forests through political arrangements supported by uncontrolled and chaotic cutting commissions. Lately, they have become more and more aggressive, as if chasing after quality wood would be the priority of life on the planet. Other smart guys don't want the wood of the forest as much as its space and they destroy the massive forests to discover new spaces good for construction of any kind, to the detriment of the forested areas and they go on until the fires of the woods in the hot and dry periods, in order to it quickly deserts the planet for mean purposes to replace various constructions. On the other hand, there is no well-guarded surveillance and surveillance of all the forests of the planet, so that they are totally protected against fires, which can occur alone if the necessary conditions of protection and protection are not respected. In addition, such fires are becoming increasingly difficult to extinguish, sometimes only after the entire forest or much of it has burned.

After we managed to balance the energy deficit of the planet a little with the help of green energies after we 
stopped the destruction of ozone by the desired nuclear explosions in the form of experiments on the planet, after the terrestrial shield started to recover and the holes in it narrowed, effectively in recent years, there are now individuals who cut or burn the forests of the planet and who should be stopped as quickly as possible and prevented from doing such reprehensible acts.

Today, there are variants that propose the use of renewable energies or others that advance the formula of nuclear energy (Petrescu and Calautit, 2016a; 2016b; Petrescu, 2011; 2012; 2014; 2019; Petrescu and Petrescu, 2011; 2012; 2014; 2019a-b; Petrescu et al., 2016a-c; 2017a-f), leaving aside the aspects related to serious accidents registered in the past and the extremely dangerous situations that this last solution can involve.

What constitutes a truth unmistakable in this context, however, is that humanity agrees in accepting the idea that the future of energy is not related to oil, coal or natural gas.

Currently, these sources provide about $87 \%$ of the total energy consumption globally, but they are toxic to all environmental components, which is an alarm signal with a view to ensuring a healthy life for our planet and civilization in the future.

Realizing that in their turn, oil reserves are depleted and correlated consumption records impressive rates, statistics prepared by specialists in this field have revealed that in less than a century, humanity risks reaching the bottom of the sack, oil wells around the world. The planet is going to become completely destroyed.

On the other hand, today, more than ever, new gas and oil deposits have been discovered which, at the current consumption level, could provide the planet's energy for at least 2000 years, which eases the tense situation created with the onset of the crisis energy from the 1980s, when the classic resources seemed to run out of time.

At the top of the new classical resources are the gases of the system about the existence of which was known for a long time but which could not then be extracted due to the lack of advanced technologies, which today exist and bring us daily huge quantities of gases extracted from the deep. Only these reserves and it would be sufficient to maintain an energy balance for mankind for another 2000 years, but we cannot rely solely on this aspect today after having energy problems, being permanently obliged to discover new alternative sources. In fact, researchers from all over the world are discovering new possible energy sources every year. Classic fuels can be industrially re-engineered or synthesized today so that they will run out even if not fast but slowly no longer an imminent danger to the planet. British researchers have long been able to produce classic fuels from the air by using atmospheric carbon and so much in the air today. A group of prestigious scientists from a Swiss university recently managed to obtain high-quality gasoline fuels usable in the aeronautical industry by using atmospheric air and photovoltaic solar energy. A plant of this kind spread over several hectares would be able to produce kerosene in industrial quantities sufficient for the needs of the planet not only for aviation but also for the total consumption of motor vehicles even if they would remain all on classic engines and this only from air and energy photovoltaic solar. There are already three large plants installed in the world today that transform the existing gas for at least two thousand years into kerosene, petrol, diesel, oils, etc.

So we can have in the future any type of classic fuel either made from the air or obtained from gases extracted in large quantities from the depth.

The ethical problem is now if we can afford to spend a lot more time burning classic fossil fuels, knowing that they pollute the planet's atmosphere a lot, producing among other things the effect of greenhouse and global warming.

These are the premises that underlie the intense efforts of an increasing number of world leaders in the field of alternative energy options, meant to gradually replace everything we know today as fuel-based energy sources.

According to expert estimates, by 2035, renewable energy will supply about $25 \%$ of the world's energy judging by the global consumer reaction following the tragic nuclear accident in Fukushima, the process could even register a considerable acceleration.

With a view to identifying viable alternatives, scientists do not step aside from the advancement of some of the most surprising solutions, starting from a few already tested and recognized as efficient, such as hydropower, wind power or that provided by solar parks and continuing with others, less familiar, but worth mentioning: Kinetic energy, wave energy, tidal energy, geothermal energy and other such proposals that even if today might seem bizarre, in the future could turn into truly miraculous solutions.

By devoting much more attention to the slightly more common variants, we could say that they continue to arouse the interest of many teams of researchers involved in the work of identifying new energy sources.

Kinetic energy - a proposal as interesting as it is controversial, is a topic of controversy, considering that it proposes the fruition of the movements of the human body for the purpose of producing energy, as happens when pedaling is used, for example to generate the energy needed for the dynamo that lights up the light bulb of a bicycle. Opinions are divided: If some consider that fitness centers around the world can use this kind of energy to their own advantage and that this model can be extrapolated to the global level, others are skeptical, 
although they do not deny the possibility of equipping the pavements with facilities to its extent; it captures the energy produced by the people who pass on their surface. Even though it would seem hilarious to rely on the energy obtained in this way because we are no longer in the stone age the idea can be somewhat twisted and used quite differently in a higher way. In fact, starting from the observation that plants and humans (including animals) have a superior way of producing and using energy, bioenergy models can be created in the future to be used successfully in various fields (Aversa et al., 2016a-o).

Geothermal energy - is a spectacular alternative, which proposes the use of the energy source that has its origin at the Earth's core, more precisely somewhere about $4000 \mathrm{~m}$ deep in the Earth - a source "with an indefinite employment contract", as stated, not without the trace of maliciousness, James Warwick, from the Department of Alternative Energy at NASA (USA).

Iceland is the land where this resource is fully exploited and with the help of five geothermal plants, it is possible to cover approximately $25 \%$ of the national energy needs.

Renewable energies have appeared in recent years, especially on the basis of wind or solar. All this represents an essential help for our planet and must be implemented in spite of the difficulties encountered with them. The biggest problem with wind and solar energy is the variation of production. When the strong wind blows the energy produced is very high and if the wind slows the wind energy production decreases very much, it can even reach zero levels in certain areas for some periods of time even in the conditions where the installation of the wind turbines is done only in areas with strong wind most of the year. At solar installations, regardless of their constructive type, the energy produced is also variable depending on the solar intensity and in the autumn-winter periods when the sky is more cloudy the solar energy produced decreases considerably, making these installations an uncertain source of energy for certain periods. Thus the extremely friendly and generous solar energy becomes a burden for the users because when it is no longer produced it has to be replaced with another energy source, in very large quantities.

We cannot give up such renewable, green and friendly energies, such as solar and wind energy and for this reason, it is good to have different energy sources on the planet so we can combine them according to the current situation. They will be replaced and complemented mutually advantageously by a well thought out and implemented a harmonious combination. We discussed these aspects and the possibility of energy exchange and energy conservation (Aversa et al., 2017; Petrescu et al., 2016a; 2016d). We will present a new idea in this regard in this paper.

\section{Materials and Methods}

There is more and more talk of energy extracted from the sea or the ocean, but today when we have come to know more types of extraction of energy from the seas and oceans, the actual amount of energy extracted from the waters of the seas and oceans is still low on the planetary level.

The seas and oceans provide us with a vast source of renewable energy, especially, but not exclusively, along the Atlantic coast. Currently, technologies are being developed in the field of ocean energy, in order to exploit the potential of tides and waves, as well as the differences in temperature and salinity.

Developing this emerging sector will help us meet our goals in renewable energy and reduce greenhouse gas emissions and, at the same time, could drive economic growth through innovation and create new jobs, high quality.

The EU is already supporting technological development through its research program. In the communication "Blue Growth" of September 2012, the Commission announced that it will evaluate other options and submit a proposal for action in 2013.

Planetary Ocean energy reserves are known to be huge. Thus, the internal energy, corresponding to the heating of the surface of the oceanic waters, in comparison with the fluvial ones, to say with $20 \mathrm{C}$, has a size of about $10^{\wedge} 26 \mathrm{~J}$. The kinetic energy of the oceanic currents is approximately equal to $10 \wedge 18 \mathrm{~J}$. But the humans can use only a very small amount of this energy, but also with very high costs, so this kind of energy is so little now. But the rapid depletion of mineral fuel reserves (primarily oil and natural gas), the use of which is accompanied by the pollution of the environment (including so-called "thermal" pollution and the increase in lower levels of carbon dioxide in the atmosphere ), the limited resources of uranium (from its use in energy, results in radioactive waste) and the uncertainty both of the duration, as well as of the ecological consequences for the industrial use of the thermonuclear energy, puts the scientists and engineers to pay more attention to the search for new possibilities. Cost-effective for using unlimited and non-polluting energy sources, but not only for the variation of river levels but also for the solar heat, wind and energy of the Planetary Ocean.

The broad circles of society, but also many specialists do not know, that the work on the search for methods of extracting energy from seas and oceans has gained in recent years in some countries large proportions and the prospects are becoming more promising.

The most obvious method of using the energy of the oceans is the construction of the flow of power plants (CFE). Since 1967, one such power station has been operating with a power of 240 thousand $\mathrm{kW}$, with an output of 540 thousand $\mathrm{kWh}$. The Soviet engineer 
Bernstein worked out a method of constructing CFE blocks, pushed on the water surface in the necessary places, calculated the cost-effective procedure of commissioning the $\mathrm{CFE}$, during the maximum charging hours of the electric line. His ideas were verified at CFE, built-in 1968 in Chislaia Guba, near Murmansk.

An unexpected possibility of ocean energy has become the rise of giant chelp algae, which can easily be converted into methane for energy exchange with natural gas. According to the existing data, only one hectare of chelp plantations are required for the full energy supply of each consumer.

Particular attention has been paid to ocean thermal energy conversion, i.e., obtaining electricity at the temperature difference between surface water and high pumping depth, for example when using volatile liquids such as propane in a closed cycle., Freon or ammonia. To a certain extent, analogous, but probably from a more distant perspective, is obtaining electricity on the basis of the differences between salt and fresh water, for example, sea and river water.

Not a little engineering art has been implemented in the models of electricity generators, which operate on the basis of oceanic agitation, even considering, in perspective, the construction of power stations with the power of many kilowatts. Even greater prospects promise the installation of ocean turbines on such intensive and stable currents as Golfstream.

It seems that some of the proposed energy installations can be built and can become profitable even today. But it is clear that the creative enthusiasm, art and ingenuity of the scientists will improve the existing facilities and create more prospects for the industrial use of the planetary ocean's energy resources. Hopefully, under the current conditions of scientific-technical progress, essential changes in ocean energy will occur in the coming decades.

The ocean contains extraterrestrial energy, which is received from the cosmos. It is accessible and harmless and does not pollute the environment, inexhaustible and free.

The energy of the Sun comes from the cosmos. It heats the air and forms the winds, which cause the waves. It heats the ocean which accumulates thermal energy. It causes currents, which change their direction under the influence of the Earth's rotational motion.

Also from the cosmos comes the attraction energy of the Sun and the Moon, which causes the flows and refluxes.

The ocean is not a living space but a colossal store of restless energy. Here the waves beat, the fluxes and reflux are born, the currents intersect and all of them impute with energy.

The buoys and headlights, which use the energy of the waves, impressed the coastal waters of Japan. For many years, the "whistles" of the coast guard of the United States of America operate on the basis of wave oscillations. Today, there are no localities on the shore that would not have their own inventors, who are working on creating wave energy installations.

Since 1966 two French cities meet their energy needs with the help of the energy of flows and refluxes. The power plant on the river Rans (Brittany), which consists of 24 reversible turbogenerators, uses this energy. Its power is $240 \mathrm{MW}$, one of the most powerful hydroelectric plants in France.

In the '70s the energy situation changed. Each time, when suppliers in the Middle East, Africa and South America raise oil prices, tidal energy has become more attractive as it competes quite well in price with the classic types of fuel. Soon in the Soviet Union, South Korea and England increased interest in the contour of the shoreline and the possibility of creating power plants, which use the energy of the tides and began to invest money for scientific research in this field. Relatively not long ago, a group of scientists in the field of oceanology determined that the Gulfstream near Florida has a speed of 5 miles per hour. The idea of using this hot water stream was quite appealing.

Is this possible? Will giant turbines and underwater propellers, reminiscent of windmills, generate electricity, extracting energy from currents and waves?

This will be the conclusion of the McArthur Committee, which was under the aegis of the National Directorate for Ocean and Atmospheric Research in Miami (Florida) in 1974. The opinion of all was that there were some problems, but that could be solved in the case of the allocation of money, because "In this project, there was nothing that would have exceeded the possibilities of engineering and technological thinking since then."

One scientist, more optimistic than others, predicted that the electricity obtained from Golfstream's energy would be able to compete with electricity traditionally obtained in the 1980s.

In the ocean, there is a wonderful environment for maintaining life, including food, salt and other minerals. In this environment, oxygen dissolved in water "feeds" all marine animals starting with the smallest and continuing with the largest, from the amoeba to the shark. The carbon dioxide dissolved in water also maintains the life of all sea plants, from unicellular algae to brown algae reaching the height of 60-90 m.

A scientist in biology is enough to take just one step forward, to go from the view that the ocean is a natural life-sustaining system to the view that it is also an energy system.

With the support of the American navy in the mid1970s, a group of oceanography specialists, marine engineers and divers created the first marine energy farm at $12 \mathrm{~m}$ depth in the Pacific Ocean, near the city of San Clement. The farm was not large. She thought it was just an experiment. On the farm grew giant, brown Californian algae. 
According to the director of this project, Dr. Howard A. Wilcoks, a member of the Marine and Oceanic Systems Research Center in San Diego (California), "Up to $50 \%$ of the energy of these algae will be converted into fuels" natural gas methane. Future ocean farms, which will grow brown algae on an area of 40,000 ha, will be able to give such energy that it will be enough to meet the energy needs of an American city with a population of 50,000 people.

The ocean has always been rich in energy, such as waves, tides and currents. Nowadays, when the need for new fuels has increased, oceanographers, chemists, physicists, engineers and technologies are drawing more and more attention to the ocean as a potential source of energy.

Lots of salts are dissolved in the ocean. Can salinity be used as a source of energy?

Maybe. The high concentration of salts in the ocean has brought a number of researchers from the University of Oceanography of La-Colla (California) and other scientific centers to the idea of creating such facilities. They believe that batteries can be built in order to obtain a large amount of energy, in which there will be reactions between salt and freshwater.

The temperature of the water in the ocean in different places is different. Between the Tropic of Cancer and the Tropic of Capricorn, it heats up to $27^{\circ} \mathrm{C}$. At a depth of $600 \mathrm{~m}$ the temperature drops to 2$3.5^{\circ} \mathrm{C}$. The question arises: Can the temperature difference be used to obtain energy? Will the energy system, submerged in water, produce energy?

Yes and this is possible.

In the twenties of our century Jorge Clode, gifted, firm and very insistent, French physicist, researched this possibility. Choosing an ocean sector near Cuba, after a series of failures to obtain an installation with the power of $22 \mathrm{~kW}$. This was a breakthrough in science and was supported by many scholars.

Using the hot water from the surface and the cold water from the bottom and thus creating a technology, we have all that is needed to produce electricity, said those who were on the side of using the thermal energy of the ocean. "According to our calculations, on the surface of the water, there are energy reserves that exceed 10,000 times the energy required to meet the world requirements".

"Unfortunately, skeptics said, Jorge Clode only got $22 \mathrm{~kW}$ of electricity. Did he give this profit? "He did not give, because Clode to get this $22 \mathrm{~kW}$ spent $80 \mathrm{~kW}$ for the work of his pumps.

Today, a professor at the University of Oceanography in La-Colla makes the totals more careful. According to his calculations, using modern technology will create energy installations (CDTs), which will use for the production of electricity the difference of temperatures in the ocean, which will produce twice as much energy than is necessary to meet the world's needs.

Of course, this prognosis is upheld, but even if he were right, the results would not help solve global energy problems. It is clear that access to the CTD's electricity reserves opens the doors to great possibilities, but (at least until now) electricity does not lift aircraft, does not move cars, does not cross ships.

But airplanes, cars can be started up with the help of gas, which can be removed from the water, but water in the seas is enough. This gas is hydrogen, which can be used as a fuel. Hydrogen is one of the most common chemical elements in the Universe. In the ocean, it is found in every drop of water. The $\mathrm{HOH}$ formula says that the water molecule consists of two hydrogen atoms and one oxygen atom. Hydrogen extracted from water can be burned as fuel and can be used not only to operate various mechanisms but also to obtain electricity.

More and more enthusiastic chemists and engineers flock to the "hydrogen energy" of the future, because the hydrogen obtained holds well: In tanks in the form of pressurized gas or in cryogenic containers at $-203^{\circ} \mathrm{C}$. It can be kept and in solid-state after interaction with the iron and titanium or magnesium alloy to form metal hybrids.

In the middle of the nineteenth-century methods of obtaining hydrogen from water were discovered. The most prospect of them is the electrolysis of the water (Through the water flows electricity, the result is a chemical decomposition. Hydrogen and oxygen are released and the liquid disappears).

Thus, in the ocean, which occupies $71 \%$ of the planet's surface, there are potentially different types of energy: Wave and tidal energy; the energy of chemical bonds between gases, nutrients, salts and other minerals; the hidden energy of hydrogen, which is found in water molecules; the energy of currents, moving quietly and endlessly in the ocean; Amazing reserves of energy, which can be received due to the temperature difference between surface and deep water and can be transformed into standard fuel types.

Such an amount of energy, its various forms guarantee, that in the future humanity will not collide with the energy problem. At the same time, we will not only be dependent on one or two traditional energy sources, such as the use of underground fuels and nuclear fuels.

Indeed, the inhabitants of those places where the sea often produces large waves will be able to build and use installations, which will use this energy. Those who live in the bays will be able to use the energy of the tides. For the other people, the energy of the ocean on the surface will be converted into methane, hydrogen or electricity, then transported on land by cable (Abadi, 2019; Ab-Rahman et al., 2009; Abam et al., 2012; Abdelkrim et al., 2012; Abdullah et al., 2011; 2009; Abdullah and Halim, 2009; Abouobaida, 2016; Abu-Ein, 
2009; Abu-Lebdeh et al., 2016; Agarwala, 2016; Ahmed et al., 2016; 2010; Akhesmeh et al., 2008; Al-Abbas, 2009; Al-Hasan and Al-Ghamdi, 2016; Al Smadi, 2011; Al Qadi et al., 2016a; 2016b; Aleksic and Lovric, 2011; Alhasanat et al., 2016; Ali and Shumaker, 2013; Ali et al., 2016; Al-Nasra et al., 2015; Alwetaishi, 2016; Aly and Abuelnasr, 2010; Amani, 2016; Amer et al., 2015; Anizan et al., 2011; Ascione et al., 2016; Augustine et al., 2016; Babayemi, 2016; Bakar et al., 2009; Barone et al., 2016; Bedon, 2016; Ben-Faress et al., 2019; Bier and Mostafavi, 2015; Bolonkin, 2009a; 2009b; Boucetta, 2008; Bourahla and Blakeborough, 2015; Bucinell, 2016; Budak et al., 2016; Buonomano et al., 2016a; 2016b; Cao et al., 2013; Calise et al., 2016; Campo et al., 2016; Cardu et al., 2009; Casadei, 2015; Darabi et al., 2008; Daud et al., 2008; De León et al., 2019; Demetriou et al., 2015; Dixit and Pal, 2015; Djalel et al., 2013; Dong et al., 2013; Ebrahim et al., 2012; El-Labban et al., 2013; Elliott et al., 2016; Elmeddahi et al., 2016; El-Tous, 2008; Faizal et al., 2016; Farahani et al., 2010; Farokhi and Gordini, 2015; Fathallah and Bakar, 2009; Fen et al., 2011; Feraga et al., 2009; Fontánez et al., 2019; Franklin, 1930; Fu et al., 2015; Gupta et al., 2015; Gusti and Semin, 2016; Helmy and El-Taweel, 2010; Huang et al., 2016; Iqbal, 2016; Ismail et al., 2011; Jaber and Bicker, 2016; Jafari et al., 2016; Jalil and Sampe, 2013; Jaoude and El-Tawil, 2013; Kaewnai and Wongwises, 2011; Khalifa et al., 2015; Khalil, 2015; Kamble and Kumar, 2016; Kechiche et al., 2011; Kuli et al., 2016; Kumar et al., 2015; Kunanoppadon, 2010; Kwon et al., 2010; Lamarre et al., 2016; Li et al., 2015; Lubis et al., 2009; Malomar et al., 2016; Martins et al., 2016; Marzuki et al., 2015; Mavukkandy et al., 2016; Minghini et al., 2016; Moezi et al., 2008; Mohamed et al., 2016; Mohan et al., 2012; Momani et al., 2011; Momta et al., 2015; Mondal et al., 2016; Pattanasethanon, 2010; Pisello et al., 2016; Rajput et al., 2016; Rich and Badar, 2016; Rohit and Dixit, 2016; Rulkov et al., 2016; Saikia and Karak, 2016; Sallami et al., 2016; Samantaray et al., 2016; Sepúlveda, 2016; Stavridou et al., 2015a; 2015b; Sylvester et al., 2015a; 2015b; Takeuchi et al., 2015; Theansuwan and Triratanasirichai, 2011; Thongwan et al., 2011; Tourab et al., 2011; Tsolakis and Raptis, 2011; Vernardos and Gantes, 2015; Zulkifli et al., 2009).

\section{Results and Discussion}

From ancient times the ocean is considered a great energy potential. Flows, water currents and waves produce mechanical energy. This energy through various technologies can be transformed into electrical energy.

\section{Flow and Reflux Energy}

Flows and refluxes are different from all other energy sources in that they are the result of the Earth-
Moon-Sun system. Ocean flows and reflections are known to occur due to the Moon's influence on Earth. Thus the sea-level changes along the coastline of all continents. The water level changes twice a day, occupying and releasing part of the territory of the coast, thus forming pools. The water currents, formed in these basins, can be used to bring the hydro turbines in motion, which, being combined with generators, can produce electricity. The higher the fluxes, the more energy can be produced in the given place. The technology, which uses this source, is similar to hydropower technology with a low speed of water flow.

\section{Potential}

The global potential of the energy of flows and reflux is estimated at around 3000 GWT. Experts are of the opinion that only $2 \%$ or 60 GWT can be used to produce electricity. At the present economic moment, advantageous for the production of electricity are the fluxes and refluxes with an amplitude of over $5 \mathrm{~m}$.

In some regions, the use of the energy of the flows and refluxes is quite attractive, especially in the coastal regions and in the deltas of the rivers with an amplitude of the flows and refluxes greater than the environment. Such conditions can be found, for example, in Canada, where the average amplitude is $10.8 \mathrm{~m}$, or in the River Severn in England, where the average amplitude reaches $8.8 \mathrm{~m}$. Large projects in these places are economically advantageous.

\section{Development}

Over the past forty years, interest in the use of energy flows and reflux has been steadily increasing. Initially, the attention of the scientists was mainly concentrated in the rivers, where large quantities (quantities) of water at high speeds pass through narrow channels. Engineers believe that by blocking the riverbeds with dams and imposing water through the turbines, electricity can be generated effectively. From a technical point of view, they were right. But it was obvious the negative impact on the environment of these projects.

Today there are industrial electric stations, which work on the basis of the energy of flows and reflux: The station built-in 1967 in the river La Rans near the town of Sen-Malo (France) with a capacity of $240 \mathrm{MW}$, the 1 MW station on the White Sea, Russia, completed in 1969 and the 16 MW station in Nova Scotia, Canada. The problems, related to the environment, have stopped the further development of the technology, based on blocking the river bank.

The electric station on the river La Rans has turbines, which can operate under pumps; thus, the installation can function as a pumping-accumulation station for regulating network overloads. The amplitude of the flows and refluxes in the river La Rans reaches $13.4 \mathrm{~m}$. The width of the dam constitutes $760 \mathrm{~m}$. At a high level 
of water, the dam comprises the Atlantic waters in the bay. At a small level, the water flows slowly back to the sea. On its way, it comprises 24 turbines, joined by generators with a capacity of 240 MW. Electricity produced covers the city's energy needs with a population of 300,000 people.

\section{The Technology}

At the base of the traditional technology, based on the grading (blocking, blocking) of the river channel of the river, the following principle stands: The water accumulates during the flows and during the reflux periods it is directed thrown for the hydro turbines work. This method provides for the formation of the barrier (dam not too high) for fencing the territory of the river, subject to the action of the flows, allowing the current of the stream to accumulate on the oceanic side of the dam. The power generation takes place over several hours when the water level is high. This is how the electrical station on La Rans works. Then, when the water level reaches its maximum value, the dam valves close. The accumulated water flows during the reflux. The shutters are open or close in accordance with the flows, which allow the flow of water only at a current required to turn the turbines. The basic technology of electricity production is similar to the hydropower technology of low power (capacity), i.e., the water passes through turbogenerators under the action of the current. The main difference of this technology, besides the fact that the turbines are in saltwater, consists of the following. The turbines of the electric station, which work on flows and reflections, must operate at the permanent change of the speed of the water current, which influences the coefficient of use of the installed capacity.

Wave energy - this solution does not only refer to the waves of the seas and oceans, although the concept also includes their variant - the world is full of multiple waveforms, as a phenomenon consisting of the propagation of oscillations in a certain environment, reflecting the oscillation mode of a physical size according to a sinusoidal model fitted in a cyclic matrix of values. Although the expression seems quite complex, the wave can be represented graphically as a wave-like oscillation and is perfectly associable with energy from the point of view of interactive patterns.

Scientists appreciate that the energy produced by the waves of the seas and oceans, as well as the special waves obtained from the interaction of a magnetic field with an electric one (electromagnetic waves), or solar radiation, considered generators of separate waves, which characterize light propagated by an amazing speed, could be alternative sources of energy in the near future.

The first experiment that demonstrated the efficiency of such a concept was carried out in 2008, in Portugal, in the form of a dedicated energy park, located about $5 \mathrm{~km}$ from the coast, which uses the huge potential of the Atlantic Ocean waves.

Tidal energy - similar to the previous one, the energy generated by the tide phenomenon that occurs under the action of the monthly attraction, is a considerable source of alternative energy, although accessible only at certain coastal points of the globe. The tidal amplitude, however, is truly impressive, being able to reach elevations of 14 to $18 \mathrm{~m}$, which generates water level oscillations onshore - an opportunity that can be exploited in the form of gigantic "accumulation lakes", like artificial estuaries (or natural), meant to store water in the short term and to capture the energy generated by it both at the inlet and at the outlet of the basin, respectively at the flow and at reflux.

Experts estimate that such a solution could provide electricity about one hundred thousand times greater than the total of existing hydroelectric plants on the surface of the Earth today.

Near the western coast of Australia, near the surface of the ocean, three beacons float, resembling some huge jellyfish, tied with a rope at the bottom of the (Fig. 1). Due to the ingenuity of the Australians, these machines produce electricity.

The steel machinery, with a width of over ten meters, are balanced by the waves of the Indian Ocean. By constantly processing water movements, beacons generate about $5 \%$ of the electricity used by a nearby military base, located in Garden Island, a suburb of Sydney's capital, the New York Times reports.

The huge buoys are part of a pilot project by Carnegie Wave Energy in Australia, which is trying to develop alternative energy methods.

These machines began to generate 240 kilowatts each for Australia's largest naval base, HMAS Stirling. They also contribute to the operation of a desalination plant, which converts seawater into drinking water for the respective base, providing approximately one-third of the necessary.

Renewable energy is not an emergency in Australia, given that the country has rich fossil fuel resources, especially coal. But this project addresses the populations on the islands that have to import expensive fuels for electricity, but also the military bases in Australia, which are trying to increase their energy security.

"All populations on the islands are looking for sustainable alternatives," said Michael E. Ottaviano, executive director of the Carnegie Institute.

The energy obtained from the waves is an excellent alternative, especially for the islands where tropical clouds affect solar energy or where the wind spoils the spectacularity of the tourist destinations.

Australia could extract the necessary energy from the waves in the future 3 times. 


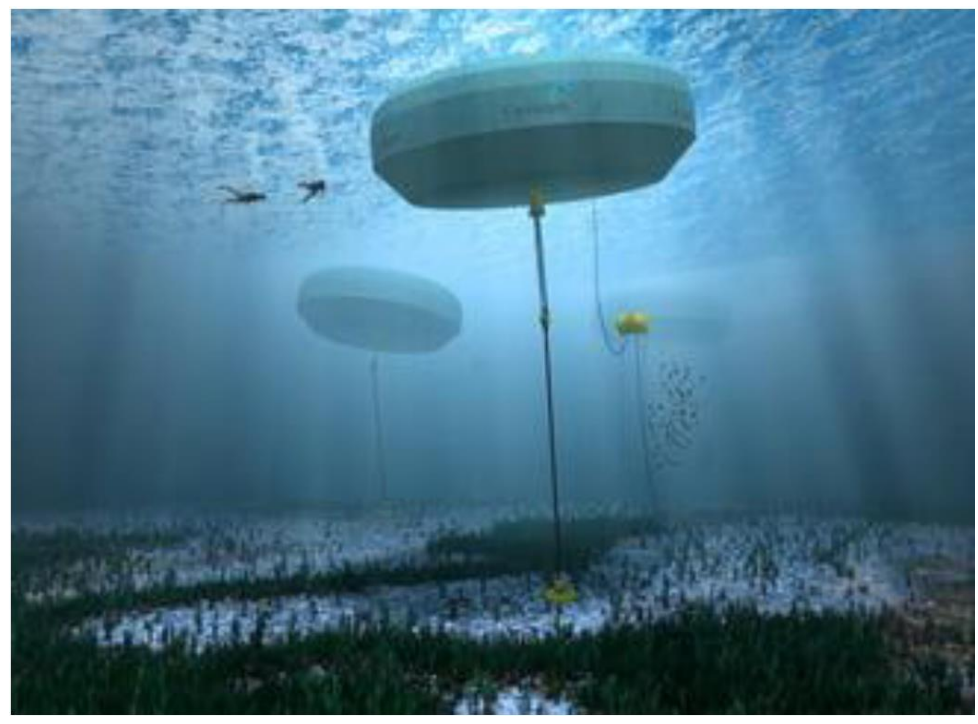

Fig. 1: The steel machineries, with a width of over ten meters, are balanced by the waves of the Indian Ocean

Given that the waves of the Indian Ocean are strong, the renewable energy obtained with their help seems a promising source, although the work of the engineers is still in an experimental stage.

The equipment currently used is easily destroyed due to storms and strong waves. In addition, being at the beginning, important investments are needed to define new and more efficient concepts. the big challenge is the creation of more resistant types of machinery in time, the reliability of the current ones being the painful problem, together with the financing of the projects otherwise.

"The biggest challenge is financing (...). Every time you want to test an idea, it costs you millions of dollars." Today's widespread energy technologies, such as nuclear facilities, have been developed for commercial purposes with government funding.

For his pilot project, Carnegie started with over $\$ 50$ million and the money came from several sources, including the Australian Government, investors and the Renewable Energy Agency of Australia. The Institute has been working on this technology since 1999 and the total investment exceeds \$ 100 million.

Carnegie is already planning to use larger and more efficient beacons from 2017, which can generate one megawatt of electricity, i.e., four times more than the current version.

Tidal energy is the energy that can be captured by exploiting the potential energy resulting from the vertical movement of the water mass at different levels or the kinetic energy due to tidal currents. The energy of the tides results from the gravitational forces of the Sun and the Moon, as well as from the earth's rotation. It is a form of renewable energy.

Tidal energy is the only renewable energy source with a high degree of predictability.
The energy of the tides does not depend on the atmospheric or climatic factors as is the case with the energy obtained from solar or derived sources.

The energy produced by the tides is influenced only by the motion in orbit of three planets that exert one on another force of gravitational attraction: Earth, Moon and Sun.

Because these planets move in orbit after very exact physical laws, the result of their action - the energy of the tides also has a very well defined character.

\section{Use of Kinetic Energy of Tidal Currents}

The method is cost-effective when the energy density developed by the tidal currents exceeds $500 \mathrm{~W} / \mathrm{m}^{2}$ (corresponding to a speed of $1 \mathrm{~m} / \mathrm{s}$ ), on a surface of at least $0.5 \mathrm{~km}^{2}$ and depths greater than $5 \mathrm{~m}$.

In areas with such characteristics, turbines with the horizontal axis (similar to wind turbines) or vertical axis are available. In order to channel the energy of tidal currents into these turbines, structures similar to the dams are constructed that have the role only of channeling the tidal energy and not of accumulation.

This variant of obtaining the tidal energy is taken into account for future projects in this field.

Use of potential energy accumulated as a result of rising water levels during the tide

The method is cost-effective when the height of the tide exceeds $8 \mathrm{~m}$. In this case, dams are built that allow the extraction of energy both during the flow and during the reflux.

During the flow, the water filling the dam drives the blades of the turbines. During reflux, when the tide reaches minimum levels, the water from the dam is allowed to flow in the opposite direction through turbines, 
also producing electricity. Unfortunately, there are only two such functional projects worldwide at the moment.

La Rance located in the estuary of the Rance River, France. The plant produces $240 \mathrm{MW}$ with the help of 24 10 MW turbines. It was inaugurated in 1966 at an updated price of 800 million euros. The investment was amortized in 1986 after 20 years. The dam has a length of $750 \mathrm{~m}$ and a height of $13 \mathrm{~m}$. The boiler produces energy both during flow and during reflux with the help of reversible turbines.

Sihwa Lake - South Korea, inaugurated in 1994, with an installed capacity of $254 \mathrm{MW}$.

The main sources of energy of the water of the seas and oceans considered at the level of the present technique are the following:

1) Marine currents that can be

- horizontal currents - due to the prevailing winds

- vertical currents - case in which the waters rise or descend from/to the depths

- marine currents - due to the movement of waters on a planetary level

- the seas - due to the monthly attraction

- the motion of the waves - due to all the solar radiation

2) Thermal energy - stored in the form of heat, the different heat content between the surface and deep water (about 30o difference)

Some studies show that the global wave energy resource was estimated at $2.7 \mathrm{TW}$. Locations with the greatest potential for wave energy include the west coast of Europe, the north coast of Great Britain and the Pacific coasts of North and South America, South Africa, Australia and New Zealand. The northern and southern temperate areas have the best sites for wave energy capture.

Out of the 2,700 gigawatts of wave generated, just over 500 gigawatts can be captured with current technology.

Manufacturers use several methods to design equipment for wave energy exploitation. This equipment can be classified either according to the location and the depth at which they are designed to operate, that is along the shore, near the shore and offshore, or according to the method used to capture the wave energy and the types of power extraction: Hydraulic ram, elastomeric hose pump, shore pump, hydroelectric turbine, air turbine and linear electric generator.

When evaluating wave energy as a type of technology, it is important to distinguish between the four most common approaches: Point absorption beacons, surface attenuators, oscillating water columns and overheating devices.
The generalized concepts of wave energy are:

- Absorbent points

- Attenuator

- Oscillating wave converter

- Oscillating water column

- Overvoltage device

- Submersible pressure difference

Point absorbers are devices that float on the surface of the water and are held in place by cables connected to the seabed. The beacons use the rise and fall of the waves to operate the hydraulic pumps and generate electricity.

Surface attenuators are devices that act similar to point absorption buoys, with several floating segments connected to one another and oriented perpendicular to the input waves. A bending motion is created by waves that supply hydraulic pumps to generate electricity.

Oscillating wave converters are devices that usually have one end fixed to a structure or seabed, while the other end is free to move. The energy is collected from the relative motion of the body compared to the fixed point. Wave converters often come in the form of floats, flaps or membranes. Some of these models incorporate parabolic reflectors as a means of increasing the wave energy at the point of capture. These capture systems use wave height and fall motion to capture energy.

Oscillating water columns are devices that can be placed on the seashore or in deeper waters offshore. With an air chamber built into the device, compressed air is blown into the rooms that force the air through an air turbine to create electricity.

Overpressure devices are devices with long structures to cover surfaces that use wave velocity to fill a tank at a level higher than that around the ocean. The potential energy in the tank height is then captured by lowpressure head turbines. The devices can be either shore or floating offshore.

Submersible pressure differentials are devices based on submersible pressure differences and are a relatively new technology that uses flexible membranes (usually reinforced rubber) to extract wave energy. These converters use pressure differences at different locations under a wave to produce a pressure difference within a closed power flow fluid system. This pressure difference is usually used to produce the flow, which drives a turbine and an electric generator. A submersible converter can be positioned either on the seafloor or in the middle of the water.

The tides occur regularly in certain coastal areas of the globe, with amplitudes that can sometimes reach 14-18 m, causing slow sea-level oscillations. The principle of the use of tidal energy in tidal power stations, in fact the only source currently used from the 
ones listed above, consists in arranging indigenous basins that make it possible to capture the energy of the water, triggered by these oscillations, both at filling (at flow) and when draining (at reflux).

In order to make efficient use of tidal energy, certain natural conditions are needed; firstly, the amplitude of the tides must be at least $5 \mathrm{~m}$ and, secondly, there is a natural basin (usually an estuary) that communicates with the ocean through a very narrow opening. These natural conditions occur only in 20 areas of the globe (such as the Atlantic shores of France, Great Britain, USA, Canada, northern Australia, eastern China, etc.).

The amount of energy available at this source, if it could be fully utilized in tidal power plants, would produce about 100,000 times more electricity than all hydropower plants currently operating around the globe. Other calculations estimate that the energy supplied annually by tides could be equivalent to that obtained by burning more than 70 thousand tons of coal.

Marine currents carry particularly high kinetic energies. Thus, it has been calculated that an ocean current with a width of about $100 \mathrm{~m}, 10 \mathrm{~m}$ depth and a velocity of $1 \mathrm{~m} / \mathrm{s}$, for one year could provide kinetic energy of about 2,000 kWh.

\section{Tidal Power Stations}

A tidal power plant recovers the energy of the tides. In tidal areas, they occur twice a day, causing the water level to rise or fall.

There are two ways to exploit tidal energy:

- Damless power plants, which use only the kinetic energy of water, similar to windmills using wind energy

- Dam power stations, which exploit the potential energy of the water, obtained by raising the level as a result of the tide

Waves are a form of energy storage transmitted by the wind, calculable energy and worthy of consideration. The calculations revealed that the waves with a height of $1 \mathrm{~m}$, the length of $40 \mathrm{~m}$ and the period of $5 \mathrm{~s}$, have an available power of about $5 \mathrm{KW}$ on a width front.

To recover the energy of the waves, schemes similar to those from the tidal power stations with a dam can be used, but due to the short period of the waves, these schemes are less efficient.

An object that floats on the waves executes a movement with an elliptical trajectory. The simplest form of harnessing this movement to recover the energy of the waves is the articulated pontoons. Modern construction is the Pelamis type consisting of several hinged cylinders, which, under the action of the waves, have relative movements that act as pistons. The pistons pump the oil under pressure through hydraulic motors that operate electric generators.
The energy produced from the thermal gradients of the seawater; is the result of the temperature difference between the waters of the oceans and the deep (cold) and surface waters (warm), based on a thermodynamic cyclical system, which vaporizes and condenses a working fluid, for example propane (propylene) or nitrogen (ammonia) to drive a turbine or thermal machine.

The energy produced from salinity gradients; In the contact area of freshwater, coming from flowing, saltwater, seas and oceans, as well as in areas where the salinity of the seawater at different depths in different, osmotic pressures can be used that can be used to produce electricity.

The first known patent to use energy from ocean waves dates from 1799 and was filed in Paris by Girard and his son.

The first to start using the wave energy were the Europeans. Countries such as Portugal, Scotland and the United Kingdom have special programs whereby the waves of the seas surrounding their shores are used to produce energy.

The world's first marine energy testing facility was established in 2003 to give birth to the development of a wave and tidal energy industry in the UK.

Aguacadoura Wave Farm was the first farm in the world to use wave energy for consumption. The farm was located $5 \mathrm{~km}$ from the sea, near Póvoa de Varzim, north of Porto, Portugal and was designed to use three energy converters on Pelamis waves to transform the movement of ocean surface waves into electricity, in value $2.25 \mathrm{MW}$ total in total installed capacity.

The financing of a $3 \mathrm{MW}$ wave farm in Scotland was announced on February 20, 2007, by the Scottish Executive, at a cost of over 4 million pounds, as part of a financing package of 13 million pounds for marine energy from Scotland. The first car was launched in May 2010.

A facility known as the Hub Wave was built off the north coast of Cornwall, England, to facilitate the development of wave energy. The Wave Hub will act as a gigantic extension cable, allowing connection to the power grid of the wave energy generation networks. The Wave Hub will initially allow $20 \mathrm{MW}$ of capacity to be connected, with potential for expansion to $40 \mathrm{MW}$.

Ocean Power Technologies (OPT Australasia Pty Ltd) is developing a wave farm connected to the network near Portland, Victoria through a $19 \mathrm{MW}$ power plant.

Since 1966, at Rance, France, a tidal power station has been operating, which uses tidal energy. It is located in the Rance estuary, formed by the river of the same name when it flows into the Gulf of Saint-Malo; Its capacity is $240 \mathrm{MW}$ and was built between 1961-1966.

The "Chausey" project envisages a similar construction in the Gulf of Le Mont St. Michael).

In Russia, in the Kislaya estuary, formed by the Tuloma and Kola rivers in the Barent Sea, a 400 MW 
installation is planned and another project targets the shores of the White Sea.

Other projects include new developments on the S-E shore of Great Britain or on the shore of the Bay of Fundy, where the US and Canada intend to build large proportions.

Japan is trying to use waves with floating devices.

The Scots announced that by 2020, 1300 MW of wave and tidal electricity generation capacity could be installed in Scottish waters, adding $100 \mathrm{MW}$ each year. The energy thus obtained reaches $10 \%$ of the electricity produced by Scotland.

\section{Conclusion}

The wave energy consists of the use of the potential energy of the fluid moved vertically relative to the level of the calm water, respectively of the kinetic energy of the moving water particles.

There are several systems for the use of wave energy for the production of electricity, among which:

- The air turbine, coupled with an electric generator, is driven by the compressed air obtained by a device that uses the energy resulting from the movement or pressure of the waves

- Low-fall turbine, which is designed to operate with large volumes of water, but having a low height, produced by the difference in level between the ridge and the void

The energy of the underwater currents, understudy, especially in the UK, is optimally achieved for an economical solution if the water depth is between 20 and $35 \mathrm{~m}$ and the speed of the sea currents is between 2 and $2.5 \mathrm{~m} / \mathrm{s}$. In general, we look for the narrow areas, where the distance between the shore of the land and some islands near the shore favors the birth of strong sea currents, capable of turning the blades of a hydraulic turbine. So far, several areas have been identified for mounting this type of turbine: The northern area of Scotland, the Channel area between the southern coast of Great Britain and the northern area of Brittany in France, the northern coast of Devon in the United Kingdom, the Strait of Messina between Sicily south of the coast of Italy, some straits between the coasts of Greece and some islands near them. Research conducted in the Romanian coastal area has not revealed the existence of submarine currents whose energy can be used.

The energy produced from the thermal gradients of seawater; is the result of the existence of the temperature difference between the waters of the oceans and the deep (cold) and surface waters (warm), based on a thermodynamic cyclic system, which vaporizes and condenses a working fluid, for example propane (propylene) or nitrogen (ammonia) to drive a turbine or thermal machine.

The problem of saltwater corrosion on the components is a major impediment and the cost of tantalum, a material used in the manufacture of heat exchangers, is very high, increasing the investment cost.

The energy produced from salinity gradients; In the contact area of freshwater, coming from flowing water, with salt water, from sea and ocean, as well as in areas where the salinity of seawater at different depths in different, osmotic pressures can be used that can be used to produce electricity.

The present paper is intended to be a plea for the extraction of energy from the seas and oceans because this energy is very large quantity from an objective point of view and in addition it is clean, renewable and sustainable, friendly and totally non-dangerous, being a very high energy which it is permanently lost, energy from which if we extract only a small amount we get enough energy for the entire planet's needs in very good and convenient conditions, without risking having nuclear residues or losses, emanations or even uncontrolled explosions that can occur at existing nuclear power plants.

The seas and oceans of the planet cover about threequarters of the total surface of our planet so that the extraction of the energy of the seas and oceans is really a permanent urge and necessity that we should see it and take it into account.

The immense advantage of the energy extracted from the waters of the seas and the oceans is the constant of its production, that is to say, the extraction of a constant amount of energy, a fact that no longer meets with other energy sources, than perhaps with nuclear energy.

\section{Acknowledgement}

This text was acknowledged and appreciated by Dr. Veturia CHIROIU Honorific member of Technical Sciences Academy of Romania (ASTR) Ph.D. supervisor in Mechanical Engineering.

\section{Funding Information}

Research contract: Contract number 36-5-4D/1986 from 24IV1985, beneficiary CNST RO (Romanian National Center for Science and Technology) Improving dynamic mechanisms internal combustion engines.

\section{!All these Matters are Copyrighted!}

Copyrights:

1. New Aircraft (New Ionic or Beam Engines): no. 548 of 22-04-2010 [cgiywDssin], Aerospace Engineering

2. Some Few Specifications About the Doppler Effect to the Electromagnetic Waves: 636 of 28-05-2010 [iEtcaouxxA], physics 
3. Presenting an Atomic Model and Some Possible Applications in LASER Field: nr. 639 of 29-052010 [yncngrotfo], physics

4. Some Applications in LASER Field: no. 718 of 0907-2010 [xeujouincC], physics

5. The Energies of Today and Tomorrow: nr. 819 of 30-09-2010 [kbHquxwykr], energy engineering

6. Obtaining Energy by the Annihilation of the Matter with Antimatter - The Battle for Energy: nr. 1068 of 13.03.2011 [GfEqpGDzeh], Energy Engineering

\section{Author's Contributions}

All the authors contributed equally to prepare, develop and carry out this manuscript.

\section{Ethics}

This article is original and contains unpublished material. Authors declare that are not ethical issues and no conflict of interest that may arise after the publication of this manuscript.

\section{References}

Abadi, M.M.L., 2019. Dynamic reliability analysis of steel moment frames using Monte Carlo technique. Am. J. Eng. Applied Sci., 12: 204-213.

DOI: 10.3844/ajeassp.2019.204.213

Abam, F.I., I.U. Ugot and D.I. Igbong, 2012. Performance analysis and components irreversibilities of a (25 MW) gas turbine power plant modeled with a spray cooler. Am. J. Eng. Applied Sci., 5: 35-41.

DOI: 10.3844/ajeassp.2012.35.41

Abdelkrim, H., S.B. Othman, A.K.B. Salem and S.B. Saoud, 2012. Dynamic partial reconfiguration contribution on system on programmable chip architecture for motor drive implementation. Am. J. Eng. Applied Sci., 5: 15-24.

DOI: 10.3844/ajeassp.2012.15.24

Abdullah, H. and S.A. Halim, 2009. Electrical and magnetoresistive studies $\mathrm{Nd}$ doped on La-Ba-Mn- $\mathrm{O}_{3}$ manganites for low-field sensor application. Am. J. Eng. Applied Sci., 2: 297-303.

DOI: 10.3844/ajeassp.2009.297.303

Abdullah, M., A. F.M. Zain, Y.H. Ho and S. Abdullah, 2009. TEC and scintillation study of equatorial ionosphere: A month campaign over sipitang and parit raja stations, Malaysia. Am. J. Eng. Applied Sci., 2: 44-49. DOI: 10.3844/ajeassp.2009.44.49

Abdullah, M.Z., A. Saat and Z. Hamzah, 2011. Optimization of energy dispersive x-ray fluorescence spectrometer to analyze heavy metals in moss samples. Am. J. Eng. Applied Sci., 4: 355-362. DOI: 10.3844/ajeassp.2011.355.362
Abouobaida, H., 2016. Robust and efficient controller to design a standalone source supplied DC and AC load powered by photovoltaic generator. Am. J. Eng. Applied Sci., 9: 894-901.

DOI: 10.3844/ajeassp.2016.894.901

Ab-Rahman, M.S., H. Guna, MH. Harun, SD. Zan and K. Jumari, 2009. Cost-effective fabrication of selfmade $1 \times 12$ polymer optical fiber-based optical splitters for automotive application. Am. J. Eng. Applied Sci., 2: 252-259.

DOI: 10.3844/ajeassp.2009.252.259

Abu-Ein, S., 2009. Numerical and analytical study of exhaust gases flow in porous media with applications to diesel particulate filters. Am. J. Eng. Applied Sci., 2: 70-75. DOI: 10.3844/ajeassp.2009.70.75

Abu-Lebdeh, M., G. Pérez-de León, S.A. Hamoush, R.D. Seals and V.E. Lamberti, 2016. Gas atomization of molten metal: Part II. Applications. Am. J. Eng. Applied Sci., 9: 334-349. DOI: 10.3844/ajeassp.2016.334.349

Agarwala, S., 2016. A perspective on 3D bioprinting technology: Present and future. Am. J. Eng. Applied Sci., 9: 985-990.

DOI: 10.3844/ajeassp.2016.985.990

Ahmed, M., R. Khan, M. Billah and S. Farhana, 2010. A novel navigation algorithm for hexagonal hexapod robot. Am. J. Eng. Applied Sci., 3: 320-327. DOI: 10.3844/ajeassp.2010.320.327

Ahmed, M.K., H. Haque and H. Rahman, 2016. An approach to develop a dynamic job shop scheduling by fuzzy rule-based system and comparative study with the traditional priority rules. Am. J. Eng. Applied Sci., 9: 202-212.

DOI: 10.3844/ajeassp.2016.202.212

Akhesmeh, S., N. Pourmahmoud and H. Sedgi, 2008. Numerical study of the temperature separation in the ranque-hilsch vortex tube. Am. J. Eng. Applied Sci., 1: 181-187. DOI: 10.3844/ajeassp.2008.181.187

Al Qadi, A.N.S., M.B.A. ALhasanat, A. AL Dahamsheh and S. AL Zaiydneen, 2016a. Using of box-benken method to predict the compressive strength of selfcompacting concrete containing Wadi Musa bentonite, Jordan. Am. J. Eng. Applied Sci., 9: 406-411. DOI: 10.3844/ajeassp.2016.406.411

Al Qadi, A.N.S., M.B.A. Alhasanat and M. Haddad, 2016b. Effect of crumb rubber as coarse and fine aggregates on the properties of asphalt concrete. Am. J. Eng. Applied Sci., 9: 558-564. DOI: 10.3844/ajeassp.2016.558.564

Al Smadi, T.A., 2011. Low cost smart sensor design. Am. J. Eng. Applied Sci., 4: 162-168. DOI: 10.3844/ajeassp.2011.162.168

Al-Abbas, I.K., 2009. Reduced order models of a current source inverter induction motor drive. Am. J. Eng. Applied Sci., 2: 39-43.

DOI: 10.3844/ajeassp.2009.39.43 
Aleksic, S. and A. Lovric, 2011. Energy consumption and environmental implications of wired access networks. Am. J. Eng. Applied Sci., 4: 531-539. DOI: 10.3844/ajeassp.2011.531.539

Al-Hasan and A.S. Al-Ghamdi, 2016. Energy balance for a diesel engine operates on a pure biodiesel, diesel fuel and biodiesel-diesel blends. Am. J. Eng. Applied Sci., 9: 458-465. DOI: 10.3844/ajeassp.2016.458.465

Alhasanat, M.B., A.N. Al Qadi, O.A. Al Khashman and A. Dahamsheh, 2016. Scanning electron microscopic evaluation of self-compacting concrete spalling at elevated temperatures. Am. J. Eng. Applied Sci., 9: 119-127. DOI: 10.3844/ajeassp.2016.119.127

Ali, G.A.M., O. Fouad and S.A. Makhlouf, 2016. Electrical properties of cobalt oxide/silica nanocomposites obtained by sol-gel technique. Am. J. Eng. Applied Sci., 9: 12-16. DOI: 10.3844/ajeassp.2016.12.16

Ali, K.S. and J.L. Shumaker, 2013. Hardware in the loop simulator for multi-agent unmanned aerial vehicles environment. Am. J. Eng. Applied Sci., 6: 172-177. DOI: 10.3844/ajeassp.2013.172.177

Al-Nasra, M. Daoudb and T.M. Abu-Lebdeh, 2015. The use of the super absorbent polymer as water blocker in concrete structures. Am. J. Eng. Applied Sci., 8: 659-665. DOI: 10.3844/ajeassp.2015.659.665

Alwetaishi, M.S., 2016. Impact of building function on thermal comfort: A review paper. Am. J. Eng. Applied Sci., 9: 928-945.

DOI: 10.3844/ajeassp.2016.928.945

Aly, W.M. and M.S. Abuelnasr, 2010. Electronic design automation using object oriented electronics. Am. J. Eng. Applied Sci., 3: 121-127.

DOI: 10.3844/ajeassp.2010.121.127

Amani, N., 2016. Design and implementation of optimum management system using cost evaluation and financial analysis for prevention of building failure. Am. J. Eng. Applied Sci., 9: 281-296.

DOI: 10.3844/ajeassp.2016.281.296

Amer, S., S. Hamoush and T.M. Abu-Lebdeh, 2015. Experimental evaluation of the raking energy in damping system of steel stud partition walls. Am. J. Eng. Applied Sci., 8: 666-677.

DOI: 10.3844/ajeassp.2015.666.677

Anizan, S., K. Yusri, C.S. Leong, N. Amin and S. Zaidi et al., 2011. Effects of the contact resistivity variations of the screen-printed silicon solar cell. Am. J. Eng. Applied Sci., 4: 328-331.

DOI: 10.3844/ajeassp.2011.328.331

Ascione, F., N. Bianco, R.F. De Masi, F. de Rossi and C. De Stasio et al., 2016. Energy audit of health care facilities: dynamic simulation of energy performances and energy-oriented refurbishment of system and equipment for microclimatic control. Am. J. Eng. Applied Sci., 9: 814-834.

DOI: 10.3844/ajeassp.2016.814.834
Augustine, A., R.D. Prakash, R. Xavier and M.C. Parassery, 2016. Review of signal processing techniques for detection of power quality events. Am. J. Eng. Applied Sci., 9: 364-370.

DOI: 10.3844/ajeassp.2016.364.370

Aversa, R., F.I.T. Petrescu, R.V. Petrescu and A. Apicella, 2016a. Biomimetic FEA bone modeling for customized hybrid biological prostheses development. Am. J. Applied Sci., 13: 1060-1067. DOI: 10.3844/ajassp.2016.1060.1067

Aversa, R., D. Parcesepe, R.V. Petrescu, G. Chen and F.I.T. Petrescu et al., 2016b. Glassy amorphous metal injection molded induced morphological defects. Am. J. Applied Sci., 13: 1476-1482.

DOI: 10.3844/ajassp.2016.1476.1482

Aversa, R., R.V. Petrescu, F.I.T. Petrescu and A. Apicella, 2016c. Smart-Factory: Optimization and process control of composite centrifuged pipes. Am. J. Applied Sci., 13: 1330-1341.

DOI: 10.3844/ajassp.2016.1330.1341

Aversa, R., F. Tamburrino, R.V. Petrescu, F.I.T. Petrescu and M. Artur et al., $2016 \mathrm{~d}$. Biomechanically inspired shape memory effect machines driven by muscle like acting NiTi Alloys. Am. J. Applied Sci., 13: 1264-1271. DOI: 10.3844/ajassp.2016.1264.1271

Aversa, R., E.M. Buzea, R.V. Petrescu, A. Apicella and M. Neacsa et al., 2016e. Present a mechatronic system having able to determine the concentration of carotenoids. Am. J. Eng. Applied Sci., 9: 1106-1111. DOI: 10.3844/ajeassp.2016.1106.1111

Aversa, R., R.V. Petrescu, R. Sorrentino, F.I.T. Petrescu and A. Apicella, 2016f. Hybrid ceramo-polymeric nanocomposite for biomimetic scaffolds design and preparation. Am. J. Eng. Applied Sci., 9: 1096-1105.

Aversa, R., V. Perrotta, R.V. Petrescu, C. Misiano and F.I.T. Petrescu et al., 2016g. From structural colors to super-hydrophobicity and achromatic transparent protective coatings: Ion plating plasma assisted $\mathrm{TiO}_{2}$ and $\mathrm{SiO}_{2}$ nano-film deposition. Am. J. Eng. Applied Sci., 9: 1037-1045.

DOI: 10.3844/ajeassp.2016.1037.1045

Aversa, R., R.V. Petrescu, F.I.T. Petrescu and A. Apicella, 2016h. Biomimetic and evolutionary design driven innovation in sustainable products development. Am. J. Eng. Applied Sci., 9: 1027-1036. DOI: 10.3844/ajeassp.2016.1027.1036

Aversa, R., R.V. Petrescu, A. Apicella and F.I.T. Petrescu, 2016i. Mitochondria are naturally micro robots-A review. Am. J. Eng. Applied Sci., 9: 991-1002. DOI: 10.3844/ajeassp.2016.991.1002

Aversa, R., R.V. Petrescu, A. Apicella and F.I.T. Petrescu, 2016j. We are addicted to vitamins C and EA review. Am. J. Eng. Applied Sci., 9: 1003-1018. DOI: 10.3844/ajeassp.2016.1003.1018 
Aversa, R., R.V. Petrescu, A. Apicella and F.I.T. Petrescu, 2016k. Physiologic human fluids and swelling behavior of hydrophilic biocompatible hybrid ceramo-polymeric materials. Am. J. Eng. Applied Sci., 9: 962-972.

DOI: 10.3844/ajeassp.2016.962.972

Aversa, R., R.V. Petrescu, A. Apicella and F.I.T. Petrescu, 20161. One can slow down the aging through antioxidants. Am. J. Eng. Applied Sci., 9: 1112-1126. DOI: 10.3844/ajeassp.2016.1112.1126

Aversa, R., R.V. Petrescu, A. Apicella and F.I.T. Petrescu, 2016m. About Homeopathy or «Similia Similibus Curentur $\gg$. Am. J. Eng. Applied Sci., 9: 1164-1172. DOI: 10.3844/ajeassp.2016.1164.1172

Aversa, R., R.V. Petrescu, A. Apicella and F.I.T. Petrescu, 2016n. The Basic Elements of Life's. Am. J. Eng. Applied Sci., 9: 1189-1197. DOI: 10.3844/ajeassp.2016.1189.1197

Aversa, R., R.V. Petrescu, A. Apicella and F.I.T. Petrescu, 2016o. Flexible stem trabecular prostheses. Am. J. Eng. Applied Sci., 9: 1213-1221. DOI: 10.3844/ajeassp.2016.1213.1221

Aversa, R., R.V. Petrescu, A. Apicella and F.I.T. Petrescu, 2017. Modern transportation and photovoltaic energy for urban ecotourism. Transylvanian Review of Administrative Sciences Special Issue, pp: 5-20. DOI: 0.24193/tras.SI2017.1

Babayemi, A.K., 2016. Thermodynamics, non-linear isotherms, statistical modeling and optimization of phosphorus adsorption from wastewater. Am. J. Eng. Applied Sci., 9: 1019-1026.

DOI: 10.3844/ajeassp.2016.1019.1026

Bakar, R.A., M.K. Mohammed and M.M. Rahman, 2009. Numerical study on the performance characteristics of hydrogen fueled port injection internal combustion engine. Am. J. Eng. Applied Sci., 2: 407-415.

DOI: 10.3844/ajeassp.2009.407.415

Barone, G., A. Buonomano, C. Forzano and A. Palombo, 2016. WLHP systems in commercial buildings: A case study analysis based on a dynamic simulation approach. Am. J. Eng. Applied Sci., 9: 659-668. DOI: 10.3844/ajeassp.2016.659.668

Bedon, C., 2016. Review on the use of FRP composites for facades and building skins. Am. J. Eng. Applied Sci., 9: 713-723.

DOI: 10.3844/ajeassp.2016.713.723

Ben-Faress, M., A. Elouadi and D. Gretete, 2019. Global supply chain risk management. Am. J. Eng. Applied Sci., 12: 147-155.

DOI: 10.3844/ajeassp.2019.147.155

Bier, H. and S. Mostafavi, 2015. Structural optimization for materially informed design to robotic production processes. Am. J. Eng. Applied Sci., 8: 549-555. DOI: 10.3844/ajeassp.2015.549.555
Bolonkin, A., 2009a. Femtotechnology: Nuclear matter with fantastic properties. Am. J. Eng. Applied Sci., 2: 501-514. DOI: 10.3844/ajeassp.2009.501.514

Bolonkin, A., 2009b. Converting of matter to nuclear energy by ab-generator. Am. J. Eng. Applied Sci., 2: 683-693. DOI: 10.3844/ajeassp.2009.683.693

Boucetta, A., 2008. Vector control of a variable reluctance machine stator and rotor discs imbricates. Am. J. Eng. Applied Sci., 1: 260-265. DOI: 10.3844/ajeassp.2008.260.265

Bourahla, N. and A. Blakeborough, 2015. Similitude distortion compensation for a small scale model of a knee braced steel frame. Am. J. Eng. Applied Sci., 8: 481-488.

DOI: $10.3844 /$ ajeassp.2015.481.488

Bucinell, R.B., 2016. Stochastic model for variable amplitude fatigue induced delamination growth in graphite/epoxy laminates. Am. J. Eng. Applied Sci., 9: 635-646.

DOI: 10.3844/ajeassp.2016.635.646

Budak, S., Z. Xiao, B. Johnson, J. Cole and M. Drabo et al., 2016. Highly-efficient advanced thermoelectric devices from different multilayer thin films. Am. J. Eng. Applied Sci., 9: 356-363. DOI: 10.3844 /ajeassp.2016.356.363

Buonomano, A., F. Calise and M. Vicidomini, 2016a. A novel prototype of a small-scale solar power plant: Dynamic simulation and thermoeconomic analysis. Am. J. Eng. Applied Sci., 9: 770-788. DOI: 10.3844/ajeassp.2016.770.788

Buonomano, A., F. Calise, M.D. d'Accadia, R. Vanoli and M. Vicidomini, 2016b. Simulation and experimental analysis of a demonstrative solar heating and cooling plant installed in Naples (Italy). Am. J. Eng. Applied Sci., 9: 798-813. DOI: 10.3844/ajeassp.2016.798.813

Calise, F., M.D. dâ' Accadia, L. Libertini, E. Quiriti and M. Vicidomini, 2016. Dynamic simulation and optimum operation strategy of a trigeneration system serving a hospital. Am. J. Eng. Applied Sci., 9: 854-867. DOI: 10.3844/ajeassp.2016.854.867

Campo, T., M. Cotto, F. Marquez, E. Elizalde and C. Morant, 2016. Graphene synthesis by plasmaenhanced CVD growth with ethanol. Am. J. Eng. Applied Sci., 9: 574-583.

DOI: 10.3844 ajeassp.2016.574.583

Cao, W., H. Ding, Z. Bin and C. Ziming, 2013. New structural representation and digital-analysis platform for symmetrical parallel mechanisms. Int. J. Adv. Robotic Sys. DOI: 10.5772/56380

Cardu, M., P. Oreste and T. Cicala, 2009. Analysis of the tunnel boring machine advancement on the Bologna-Florence railway link. Am. J. Eng. Applied Sci., 2: 416-420.

DOI: $10.3844 /$ ajeassp.2009.416.420 
Casadei, D., 2015. Bayesian statistical inference for number counting experiments. Am. J. Eng. Applied Sci., 8: 730-735.

DOI: 10.3844/ajeassp.2015.730.735

Darabi, A., S.A. Soleamani and A. Hassannia, 2008. Fuzzy based digital automatic voltage regulator of a synchronous generator with unbalanced loads. Am. J. Eng. Applied Sci., 1: 280-286.

DOI: 10.3844/ajeassp.2008.280.286

Daud, H., N. Yahya, A.A. Aziz and M.F. Jusoh, 2008. Development of wireless electric concept powering electrical appliances. Am. J. Eng. Applied Sci., 1: 12-15. DOI: 10.3844/ajeassp.2008.12.15

De León, J., M., del C. Cotto and F., Márquez, 2019. Toxicology of nanomaterials on zebrafish. Am. J. Eng. Applied Sci., 12: 193-203.

DOI: 10.3844/ajeassp.2019.193.203

Demetriou, D., N. Nikitas and K.D. Tsavdaridis, 2015. Semi active tuned mass dampers of buildings: A simple control option. Am. J. Eng. Applied Sci., 8: 620-632. DOI: 10.3844/ajeassp.2015.620.632

Dixit, S. and S. Pal, 2015. Synthesis and characterization of ink (Carbon)-perovskite/polyaniline ternary composite electrode for sodium chloride separation. Am. J. Eng. Applied Sci., 8: 527-537.

DOI: 10.3844/ajeassp.2015.527.537

Djalel, D., M. Mourad and H. Labar, 2013. New approach of electromagnetic fields of the lightning discharge. Am. J. Eng. Applied Sci., 6: 369-383. DOI: 10.3844/ajeassp.2013.369.383

Dong, H., N. Giakoumidis, N. Figueroa and N. Mavridis, 2013. Approaching behaviour monitor and vibration indication in developing a General Moving Object Alarm System (GMOAS). Int. J. Adv. Robotic Sys. DOI: $10.5772 / 56586$

Ebrahim, N.A., S. Ahmed, S.H.A. Rashid and Z. Taha, 2012. Technology use in the virtual R\&D teams. Am. J. Eng. Applied Sci., 5: 9-14. DOI: 10.3844/ajeassp.2012.9.14

El-Labban, H.F., M. Abdelaziz and E.R.I. Mahmoud, 2013. Modification of carbon steel by laser surface melting: Part I: Effect of laser beam travelling speed on microstructural features and surface hardness. Am. J. Eng. Applied Sci., 6: 352-359.

DOI: 10.3844/ajeassp.2013.352.359

Elliott, A., S. AlSalihi, A.L. Merriman and M.M. Basti, 2016. Infiltration of nanoparticles into porous binder jet printed parts. Am. J. Eng. Applied Sci., 9: 128-133. DOI: 10.3844/ajeassp.2016.128.133

Elmeddahi, Y., H. Mahmoudi, A. Issaadi, M.F.A. Goosen and R. Ragab, 2016. Evaluating the effects of climate change and variability on water resources: A case study of the Cheliff Basin in Algeria. Am. J. Eng. Applied Sci., 9: 835-845. DOI: 10.3844/ajeassp.2016.835.845
El-Tous, Y., 2008. Pitch angle control of variable speed wind turbine. Am. J. Eng. Applied Sci., 1: 118-120. DOI: 10.3844/ajeassp.2008.118.120

Faizal, A., S. Mulyono, R. Yendra and A. Fudholi, 2016. Design Maximum Power Point Tracking (MPPT) on photovoltaic panels using fuzzy logic method. Am. J. Eng. Applied Sci., 9: 789-797. DOI: 10.3844/ajeassp.2016.789.797

Farahani, A.S., N.M. Adam and M.K.A. Ariffin, 2010. Simulation of airflow and aerodynamic forces acting on a rotating turbine ventilator. Am. J. Eng. Applied Sci., 3: 159-170.

DOI: 10.3844/ajeassp.2010.159.170

Farokhi, E. and M. Gordini, 2015. Investigating the parameters influencing the behavior of knee braced steel structures. Am. J. Eng. Applied Sci., 8: 567-574. DOI: 10.3844/ajeassp.2015.567.574

Fathallah, A.Z.M. and R.A. Bakar, 2009. Prediction studies for the performance of a single cylinder high speed spark ignition linier engine with spring mechanism as return cycle. Am. J. Eng. Applied Sci., 2: 713-720. DOI: 10.3844/ajeassp.2009.713.720

Fen, Y.W., W.M.M. Yunus, M.M. Moksin, Z.A. Talib and N.A. Yusof, 2011. Optical properties of crosslinked chitosan thin film with glutaraldehyde using surface plasmon resonance technique. Am. J. Eng. Applied Sci., 4: 61-65. DOI: 10.3844 /ajeassp.2011.61.65

Feraga, C.E., A. Moussaoui, A. Bouldjedri and A. Yousfi, 2009. Robust position controller for a permanent magnet synchronous actuator. Am. J. Eng. Applied Sci., 2: 388-392.

DOI: 10.3844/ajeassp.2009.388.392

Fontánez, K., A., García, M., del C Cotto-Maldonado and J. Duconge 2019. Development of Ionizing Radiation Sensors Based on Carbon Nanotubes. Am. J. Eng. Applied Sci., 12(2):185-192. DOI: 10.3844/ajeassp.2019.185.192

Franklin, D.J., 1930. Ingenious Mechanisms for Designers and Inventors. 1st Edn., Industrial Press Publisher.

Fu, Y.F., J. Gong, H. Huang, Y.J. Liu and D. Zhu et al., 2015. Parameters optimization of adaptive cashew shelling cutter based on BP neural network and genetic algorithm. Am. J. Eng. Applied Sci., 8: 648-658. DOI: 10.3844/ajeassp.2015.648.658

Gupta, P., A. Gupta and A. Asati, 2015. Ultra low power MUX based compressors for wallace and dadda multipliers in sub-threshold regime. Am. J. Eng. Applied Sci., 8: 702-716.

DOI: 10.3844/ajeassp.2015.702.716

Gusti, A.P. and Semin, 2016. The effect of vessel speed on fuel consumption and exhaust gas emissions. Am. J. Eng. Applied Sci., 9: 1046-1053. DOI: 10.3844/ajeassp.2016.1046.1053 
Helmy, A.K. and G.S. El-Taweel, 2010. Neural network change detection model for satellite images using textural and spectral characteristics. Am. J. Eng. Applied Sci., 3: 604-610.

DOI: 10.3844/ajeassp.2010.604.610

Huang, B., S.H. Masood, M. Nikzad, P.R. Venugopal and A. Arivazhagan, 2016. Dynamic mechanical properties of fused deposition modelling processed polyphenylsulfone material. Am. J. Eng. Applied Sci., 9: 1-11.

DOI: 10.3844/ajeassp.2016.1.11

Iqbal, 2016. An overview of Energy Loss Reduction (ELR) software used in Pakistan by WAPDA for calculating transformer overloading, line losses and energy losses. Am. J. Eng. Applied Sci., 9: 442-448. DOI: 10.3844/ajeassp.2016.442.448

Ismail, M.I.S., Y. Okamoto, A. Okada and Y. Uno, 2011. Experimental investigation on micro-welding of thin stainless steel sheet by fiber laser. Am. J. Eng. Applied Sci., 4: 314-320.

DOI: 10.3844/ajeassp.2011.314.320

Jaber, A.A. and R. Bicker, 2016. Industrial robot fault detection based on statistical control chart. Am. J. Eng. Applied Sci., 9: 251-263.

DOI: 10.3844/ajeassp.2016.251.263

Jafari, N., A. Alsadoon, C.P. Withana, A. Beg and A. Elchouemi, 2016. Designing a comprehensive security framework for smartphones and mobile devices. Am. J. Eng. Applied Sci., 9: 724-734.

DOI: 10.3844/ajeassp.2016.724.734

Jalil, M.I.A. and J. Sampe, 2013. Experimental investigation of thermoelectric generator modules with different technique of cooling system. Am. J. Eng. Applied Sci., 6: 1-7.

DOI: 10.3844/ajeassp.2013.1.7

Jaoude, A.A. and K. El-Tawil, 2013. Analytic and nonlinear prognostic for vehicle suspension systems. Am. J. Eng. Applied Sci., 6: 42-56.

DOI: 10.3844 /ajeassp.2013.42.56

Kaewnai, S. and S. Wongwises, 2011. Improvement of the runner design of Francis turbine using computational fluid dynamics. Am. J. Eng. Applied Sci., 4: 540-547.

DOI: 10.3844/ajeassp.2011.540.547

Kamble, V.G. and N. Kumar, 2016. Fabrication and tensile property analysis of polymer matrix composites of graphite and silicon carbide as fillers. Am. J. Eng. Applied Sci., 9: 17-30.

DOI: 10.3844/ajeassp.2016.17.30

Kechiche, O.B.H.B., H.B.A. Sethom, H. Sammoud and I.S. Belkhodja, 2011. Optimized high-frequency signal injection based permanent magnet synchronous motor rotor position estimation applied to washing machines. Am. J. Eng. Applied Sci., 4: 390-399. DOI: 10.3844/ajeassp.2011.390.399
Khalifa, A.H.N., A.H. Jabbar and J.A. Muhsin, 2015. Effect of exhaust gas temperature on the performance of automobile adsorption airconditioner. Am. J. Eng. Applied Sci., 8: 575-581. DOI: 10.3844/ajeassp.2015.575.581

Khalil, R., 2015. Credibility of 3D volume computation using GIS for pit excavation and roadway constructions. Am. J. Eng. Applied Sci., 8: 434-442.

DOI: 10.3844/ajeassp.2015.434.442

Kuli, I., T.M. Abu-Lebdeh, E.H. Fini and S.A. Hamoush, 2016. The use of nano-silica for improving mechanical properties of hardened cement paste. Am. J. Eng. Applied Sci., 9: 146-154. DOI: 10.3844/ajeassp.2016.146.154

Kumar, N.D., R.D. Ravali and PR. Srirekha, 2015. Design and realization of pre-amplifier and filters for on-board radar system. Am. J. Eng. Applied Sci., 8: 689-701. DOI: 10.3844/ajeassp.2015.689.701

Kunanoppadon, J., 2010. Thermal efficiency of a combined turbocharger set with gasoline engine. Am. J. Eng. Applied Sci., 3: 342-349.

DOI: 10.3844/ajeassp.2010.342.349

Kwon, S., Y. Tani, H. Okubo and T. Shimomura, 2010. Fixed-star tracking attitude control of spacecraft using single-gimbal control moment gyros. Am. J. Eng. Applied Sci., 3: 49-55.

DOI: 10.3844 /ajeassp.2010.49.55

Lamarre, A., E.H. Fini and T.M. Abu-Lebdeh, 2016. Investigating effects of water conditioning on the adhesion properties of crack sealant. Am. J. Eng. Applied Sci., 9: 178-186.

DOI: 10.3844/ajeassp.2016.178.186

Li, R., B. Zhang, S. Xiu, H. Wang and L. Wang et al., 2015. Characterization of solid residues obtained from supercritical ethanol liquefaction of swine manure. Am. J. Eng. Applied Sci., 8: 465- 470.

DOI: 10.3844/ajeassp.2015.465.470

Lubis, Z., A.N. Abdalla, Mortaza and R. Ghon, 2009. Mathematical modeling of the three phase induction motor couple to DC motor in hybrid electric vehicle. Am. J. Eng. Applied Sci., 2: 708-712. DOI: 10.3844/ajeassp.2009.708.712

Malomar, G.E.B., A. Gueye, C. Mbow, V.B. Traore and A.C. Beye, 2016. Numerical study of natural convection in a square porous cavity thermally modulated on both side walls. Am. J. Eng. Applied Sci., 9: 591-598.

DOI: 10.3844/ajeassp.2016.591.598

Martins, F.R., A.R. Gonçalves and E.B. Pereira, 2016. Observational study of wind shear in northeastern Brazil. Am. J. Eng. Applied Sci., 9: 484-504. DOI: 10.3844/ajeassp.2016.484.504 
Marzuki, M.A.L.B., M.H. Abd Halim and A.R.N. Mohamed, 2015. Determination of natural frequencies through modal and harmonic analysis of space frame race car chassis based on ANSYS. Am. J. Eng. Applied Sci., 8: 538-548. DOI: 10.3844/ajeassp.2015.538.548

Mavukkandy, M.O., S. Chakraborty, T. Abbasi and S.A. Abbasi, 2016. A clean-green synthesis of platinum nanoparticles utilizing a pernicious weed lantana (Lantana Camara). Am. J. Eng. Applied Sci., 9: 84-90. DOI: 10.3844 /ajeassp.2016.84.90

Minghini, F., N. Tullini and F. Ascione, 2016. Updating Italian design guide CNR DT-205/2007 in view of recent research findings: Requirements for pultruded FRP profiles. Am. J. Eng. Applied Sci., 9: 702-712. DOI: 10.3844/ajeassp.2016.702.712

Moezi, N., D. Dideban and A. Ketabi, 2008. A novel integrated SET based inverter for nano power electronic applications. Am. J. Eng. Applied Sci., 1: 219-222. DOI: 10.3844/ajeassp.2008.219.222

Mohamed, M.A., A.Y. Tuama, M. Makhtar, M.K. Awang and M. Mamat, 2016. The effect of RSA exponential key growth on the multi-core computational resource. Am. J. Eng. Applied Sci., 9: 1054-1061. DOI: 10.3844/ajeassp.2016.1054.1061

Mohan, K.S.R., P. Jayabalan and A. Rajaraman, 2012. Properties of fly ash based coconut fiber composite. Am. J. Eng. Applied Sci., 5: 29-34.

DOI: 10.3844/ajeassp.2012.29.34

Momani, M.A., T.A. Al Smadi, FM. Al Taweel and K.A. Ghaidan, 2011. GPS ionospheric total electron content and scintillation measurements during the October 2003 magnetic storm. Am. J. Eng. Applied Sci., 4: 301-306. DOI: 10.3844/ajeassp.2011.301.306

Momta, P.S., J.O. Omoboh and M.I. Odigi, 2015. Sedimentology and depositional environment of D2 sand in part of greater ughelli depobelt, onshore Niger Delta, Nigeria. Am. J. Eng. Applied Sci., 8: 556-566.

DOI: 10.3844/ajeassp.2015.556.566

Mondal, R., S. Sahoo and C.S. Rout, 2016. Mixed nickel cobalt manganese oxide nanorods for supercapacitor application. Am. J. Eng. Applied Sci., 9: 540-546. DOI: 10.3844/ajeassp.2016.540.546

Pattanasethanon, S., 2010. The solar tracking system by using digital solar position sensor. Am. J. Eng. Applied Sci., 3: 678-682.

DOI: 10.3844/ajeassp.2010.678.682

Petrescu, F.I.T. and J.K. Calautit, 2016a. About nano fusion and dynamic fusion. Am. J. Applied Sci., 13: 261-266 DOI: 10.3844/ajassp.2016.261.266

Petrescu, F.I.T. and J.K. Calautit, 2016b. About the light dimensions. Am. J. Applied Sci., 13: 321-325.

DOI: 10.3844/ajassp.2016.321.325
Petrescu, F.I.T. and R.V. Petrescu, 2011. Perspective Energetice Globale, Create Space publisher, USA. ISBN 978-1-4681-3082-9, pp: 80.

Petrescu, F.I.T. and R.V. Petrescu, 2012. News in Physics, 1st Edn., ISBN-13: 978-3848229642, pp: 82.

Petrescu, F.I.T. and R.V. Petrescu, 2014. Nuclear green energy. IJAP, 10: 3-14.

Petrescu, F.I.T. and R.V.V. Petrescu, 2019a. Nuclear hydrogen structure and dimensions. Int. J. Hydrogen Energy, 44: 10833-10837.

DOI: $10.1016 /$ j.ijhydene.2019.02.140

Petrescu, N. and F.I.T. Petrescu, 2019b. Free particle spin speed. Am. J. Eng. Applied Sci., 12: 337-341. DOI: 10.3844/ajeassp.2019.337.341

Petrescu, F.I.T., 2011. Some New Elements in Physics, Create Space publisher, USA, November 2011, ISBN 978-1-4679-4880-7, pp: 72.

Petrescu, F.I.T., 2012. Cold nuclear fusion. Plasma Physics Fusion Technology.

Petrescu, F.I.T., 2014. Nuclear fusion. Infinite Energy, 20: 44-47.

Petrescu, F.I.T., 2019. About the nuclear particles' structure and dimensions. Comp. Part. Mech., 6: 191-194. DOI: 10.1007/S40571-018-0206-7

Petrescu, F.I.T., A. Apicella and R.V. Petrescu, 2016 a. Environmental protection through nuclear energy. Am. J. Applied Sci., 13: 941-946. DOI: 10.3844/ajassp.2016.941.946

Petrescu, F.I.T., A. Apicella, A. Raffaella, R.V. Petrescu and J.K. Calautit, 2016b. Something about the mechanical moment of inertia. Am. J. Applied Sci., 13: 1085-1090. DOI: 10.3844/ajassp.2016.1085.1090

Petrescu, R.V., R. Aversa, A. Apicella, S. Li and G. Chen et al., 2016c. Something about electron dimension. Am. J. Applied Sci., 13: 1272-1276. DOI: 10.3844/ajassp.2016.1272.1276

Petrescu, R.V., R. Aversa, A. Apicella, F. Berto and S. Li et al., 2016d. Ecosphere protection through green energy. Am. J. Applied Sci., 13: 1027-1032. DOI: 10.3844/ajassp.2016.1027.1032

Petrescu, R.V., R. Aversa, S. Li, R. Bucinell and S.P. Kozaitis et al., 2017a. Electron dimensions. Am. J. Eng. Applied Sci., 10: 584-602. DOI: 10.3844/ajeassp.2017.584.602

Petrescu, R.V., R. Aversa, S.P. Kozaitis, A. Apicella and F.I.T. Petrescu, 2017b. Deuteron dimensions. Am. J. Engineering Applied Sci., 10: 649-654.

DOI: 10.3844/ajeassp.2017.649.654

Petrescu, R.V., R. Aversa, S.P. Kozaitis, A. Apicella and F.I.T. Petrescu, 2017c. Some proposed solutions to achieve nuclear fusion. Am. J. Engineering Applied Sci., 10: 703-708. DOI: 10.3844/ajeassp.2017.703.708

Petrescu, R.V., R. Aversa, S.P. Kozaitis, A. Apicella and F.I.T. Petrescu, 2017d. Some basic reactions in nuclear fusion. Am. J. Eng. Applied Sci., 10: 709-716. DOI: 10.3844/ajeassp.2017.709.716 
Petrescu, R.V., R. Aversa, A. Apicella and F.I.T. Petrescu, 2017e. Proposed solutions to achieve nuclear fusion. Engevista, 19: 1496-1507.

DOI: 10.22409/engevista.v19i5.968

Petrescu, R.V., F.I.T. Petrescu, R. Aversa and A. Apicella, 2017f. Nano Energy. Engevista, 19: 267-292. DOI: 10.22409/engevista.v19i2.760

Pisello, A.L., G. Pignatta, C. Piselli, V.L. Castaldo and F. Cotana, 2016. Investigating the dynamic thermal behavior of building envelope in summer conditions by means of in-field continuous monitoring. Am. J. Eng. Applied Sci., 9: 505-519.

DOI: 10.3844/ajeassp.2016.505.519

Rajput, R.S., S. Pandey and S. Bhadauria, 2016. Correlation of biodiversity of algal genera with special reference to the waste water effluents from industries. Am. J. Eng. Applied Sci., 9: 1127-1133. DOI: 10.3844/ajeassp.2016.1127.1133

Rich, F. and M.A. Badar, 2016. Statistical analysis of auto dilution Vs manual dilution process in inductively coupled plasma spectrometer tests. Am. J. Eng. Applied Sci., 9: 611-624. DOI: 10.3844/ajeassp.2016.611.624

Rohit, K. and S. Dixit, 2016. Mechanical properties of waste Biaxially Oriented Polypropylene metallized films (BOPP), LLDPE: LDPE films with sisal fibres. Am. J. Eng. Applied Sci., 9: 913-920. DOI: 10.3844/ajeassp.2016.913.920

Rulkov, N.F., A.M. Hunt, P.N. Rulkov and A.G. Maksimov, 2016. Quantization of map-based neuronal model for embedded simulations of neurobiological networks in real-time. Am. J. Eng. Applied Sci., 9: 973-984. DOI: 10.3844/ajeassp.2016.973.984

Saikia, A. and N. Karak, 2016. Castor oil based epoxy/clay nanocomposite for advanced applications. Am. J. Eng. Applied Sci., 9: 31-40. DOI: 10.3844 /ajeassp.2016.31.40

Sallami, A., N. Zanzouri and M. Ksouri, 2016. Robust diagnosis of a DC motor by bond graph approach. Am. J. Eng. Applied Sci., 9: 432-438.

DOI: 10.3844/ajeassp.2016.432.438

Samantaray, K.S., S. Sahoo and C.S. Rout, 2016. Hydrothermal synthesis of CuWO4-reduced graphene oxide hybrids and super capacitor application. Am. J. Eng. Applied Sci., 9: 584-590. DOI: 10.3844/ajeassp.2016.584.590

Sepúlveda, J.A.M., 2016. Outlook of municipal solid waste in Bogota (Colombia). Am. J. Eng. Applied Sci., 9: 477-483.

DOI: 10.3844/ajeassp.2016.477.483

Stavridou, N., E. Efthymiou and C.C. Baniotopoulos, 2015a. Welded connections of wind turbine towers under fatigue loading: Finite element analysis and comparative study. Am. J. Eng. Applied Sci., 8: 489-503. DOI: 10.3844/ajeassp.2015.489.503
Stavridou, N., E. Efthymiou and C.C. Baniotopoulos, 2015b. Verification of anchoring in foundations of wind turbine towers. Am. J. Eng. Applied Sci., 8: 717-729. DOI: 10.3844/ajeassp.2015.717.729

Sylvester, O., I. Bibobra and O.N. Ogbon, 2015a. Well test and PTA for reservoir characterization of key properties. Am. J. Eng. Applied Sci., 8: 638-647. DOI: 10.3844/ajeassp.2015.638.647

Sylvester, O., I. Bibobra and O. Augustina, $2015 \mathrm{~b}$. Report on the evaluation of Ugua J2 and J3 reservoir performance. Am. J. Eng. Applied Sci., 8: 678-688. DOI: 10.3844/ajeassp.2015.678.688

Takeuchi, T., Y. Kinouchi, R. Matsui and T. Ogawa, 2015. Optimal arrangement of energy-dissipating members for seismic retrofitting of truss structures. Am. J. Eng. Applied Sci., 8: 455-464.

DOI: 10.3844 /ajeassp.2015.455.464

Theansuwan, W. and K. Triratanasirichai, 2011. The biodiesel production from roast Thai sausage oil by transesterification reaction. Am. J. Eng. Applied Sci., 4: 130-132.

DOI: 10.3844/ajeassp.2011.130.132

Thongwan, T., A. Kangrang and S. Homwuttiwong, 2011. An estimation of rainfall using fuzzy setgenetic algorithms model. Am. J. Eng. Applied Sci., 4: 77-81. DOI: 10.3844/ajeassp.2011.77.81

Tourab, W., A. Babouri and M. Nemamcha, 2011. Experimental study of electromagnetic environment in the vicinity of high voltage lines. Am. J. Eng. Applied Sci., 4: 209-213.

DOI: 10.3844/ajeassp.2011.209.213

Tsolakis, A.D. and K.G. Raptis, 2011. Comparison of maximum gear-tooth operating bending stresses derived from niemann's analytical procedure and the finite element method. Am. J. Eng. Applied Sci., 4: 350-354. DOI: 10.3844/ajeassp.2011.350.354

Vernardos, S.M. and C.J. Gantes, 2015. Cross-section optimization of sandwich-type cylindrical wind turbine towers. Am. J. Eng. Applied Sci., 8: 471-480. DOI: 10.3844/ajeassp.2015.471.480

Zulkifli, R., K. Sopian, S. Abdullah and M.S. Takriff, 2009. Experimental study of flow structures of circular pulsating air jet. Am. J. Eng. Applied Sci., 2: 171-175. DOI: 10.3844/ajeassp.2009.171.175

\section{Source of Figures}

Figure 1: http://tb.ziareromania.ro/Cum-setransforma-valurile-marii-in-electricitate--Cea-maimare-provocare/d3c051ec9ec30dd8f5/327/0/1/70/Cumse-transforma-valurile-marii-in-electricitate--Cea-maimare-provocare.jpg 